\title{
Pengembangan Perangkat Pembelajaran Matematika Berbasis Creative Problem Solving (CPS) Pada Materi Aritmatika Sosial
}

\author{
Nur Solihin ${ }^{1}$, Putri Yuanita ${ }^{2}$, Maimunah ${ }^{3}$ \\ 1,2,3 Program Studi Pendidikan Matematika, Fakultas Keguruan dan Ilmu Pendidikan, Universitas Riau \\ Jl. Bina Widya Simpang Baru, Pekanbaru \\ nursolihinpentika@gmail.com
}

\begin{abstract}
This research is motivated by learning that is not in accordance with the 2013 curriculum. This occurs due to a lack of planning in the learning process, so that students do not find their own mathematical concepts to be studied. Therefore, we need a form of planning in the learning process so that learning is in accordance with the 2013 Curriculum. The purpose of this research is to produce mathematics learning tools (Syllabus, Learning Device Design (LDD) and Student Activity Sheet (SAS)) based on Creative Problem Solving on social arithmetic material that meets aspects of validity and practicality. This research is a research and Development research in the form of research procedures carried out by creating a particular product and testing the effectiveness of the product. Based on the data analysis of the validation results by the validator on the syllabus, LDD and SAS using the creative problem-solving model on social arithmetic material for class VII SMP/MTs, with an average score for the syllabus 3.70, the average score for lesson plans is 3.57, the mean score for SAS was 3.55. Overall, the syllabus, lesson plans and SAS are considered very valid.
\end{abstract}

Keywords: Development Research, Creative Problem Solving, Social Arithmetic

\begin{abstract}
Abstrak
Penelitian ini dilatarbelakangi oleh pembelajaran yang belum sesuai dengan kurikulum 2013. Hal ini terjadi dikarenakan kurangnya perencanaan dalam proses pembelajaran, Sehingga siswa tidak menemukan sendiri konsep matematika yang akan dipelajari. Oleh sebab itu dibutuhkan suatu bentuk perencanaan dalam proses pembelajaran agar pembelajaran sesuai dengan Kurikulum 2013. Tujuan penelitian ini adalah untuk menghasilkan perangkat pembelajaran matematika (Silabus, Rancangan Perangkat Pembelajaran (RPP) dan Lembar Aktivitas Siswa (LAS)) berbasis Creative Problem Solving pada materi aritmatika sosial yang memenuhi aspek validitas dan aspek praktikalitas. Penelitian ini merupakan penelitian pengembangan (Research and Development) yaitu berupa prosedur penelitian yang dilakukan dengan menciptakan suatu produk tertentu dan menguji keefektivan produk tersebut. Berdasarkan analisis data hasil validasi oleh validator terhadap silabus, RPP dan LAS dengan menggunakan model Creative Problem Solving pada materi aritmatika sosial untuk kelas VII SMP/MTs, dengan rata-rata skor untuk silabus 3,70, rata-rata skor untuk RPP 3,57, rata-rata skor untuk LAS 3,55. Secara keseluruhan silabus, RPP dan LAS dinilai sangat valid.
\end{abstract}

Kata kunci: Penelitian Pengembangan, Creative Problem Solving, Aritmatika Sosial

Copyright (c) 2021 Nur Solihin, Putri Yuanita, Maimunah

$\triangle$ Corresponding author: Nur Solihin

Email Address: nursolihinpentika@gmail.com (Jl. Bina Widya Simpang Baru, Pekanbaru)

Received 22 July 2021, Accepted 26 August 2021, Published 13 September 2021

\section{PENDAHULUAN}

Perencanaan pembelajaran adalah suatu cara yang merumuskan untuk membuat rencana kegiatan pembelajaran dapat berjalan dengan baik, disertai dengan berbagai langkah guna memperkecil kesenjangan yang terjadi sehingga kegiatan tersebut mencapai tujuan yang ditetapkan (Hamzah B Uno, 2012). Perencanaan pembelajaran dapat dilakukan dengan membuat perangkat pembelajaran. Adanya perangkat pembelajaran berarti langkah pembelajaran yang akan dilakukan telah disusun secara terstruktur sesuai dengan tujuan yang ingin dicapai. Oleh sebab itu, kualitas perangkat yang digunakan juga menentukan kualitas pembelajaran. Untuk menghasilkan perangkat yang berkualitas baik maka 
perangkat pembelajaran harus disusun dengan matang dan sesuai dengan aturan yang telah ditetapkan dalam standar proses (Permendikbud No.22 Tahun 2016).

Perangkat pembelajaran yang diperlukan dalam mengolah proses pembelajaran dapat berupa buku siswa, silabus, Rencana Pelaksanaan Pembelajaran (RPP), Lembar Aktivitas Siswa (LAS), instrumen evaluasi atau Tes Hasil Belajar (THB) serta media pembelajaran (Ibrahim dalam Trianto, 2015). Perencanaan perangkat pembelajaran dirancang dalam bentuk silabus dan RPP yang mengacu pada standar proses (Permendikbud No.22 Tahun 2016). Silabus merupakan acuan penyusunan kerangka pembelajaran untuk setiap bahan kajian mata pelajaran. RPP merupakan salah satu komponen yang penting dan perlu diperhatikan, karena hal tersebut akan memberikan gambaran dan acuan pelaksanaan pembelajaran. RPP juga akan membantu guru dalam menetapkan langkah-langkah pembelajaran yang berlangsung di kelas. RPP dikembangkan dari silabus untuk mengarahkan kegiatan pembelajaran siswa dalam upaya mencapai Kompetensi Dasar (KD). Setiap pendidik pada satuan pendidikan berkewajiban menyusun RPP secara lengkap dan sistematis agar pembelajaran berlangsung secara interaktif, inspiratif, menyenangkan, menantang, efisien, dan memotivasi siswa untuk berpartisipasi aktif sesuai dengan yang dituntut dalam Kurikulum 2013.

Peneliti melakukan wawancara dengan guru mata pelajaran matematika pada dua Sekolah Menengah Pertama di Pekanbaru untuk mengetahui implementasi Kurikulum 2013. Berdasarkan hasil wawancara dari tiga orang guru matematika diperoleh informasi bahwa dalam proses pembelajaran guru tersebut menggunakan silabus yang disediakan oleh pemerintah sedangkan dalam membuat RPP guru lebih banyak mencari dari internet. RPP dari internet tersebut hanya dimodifikasi seperlunya saja misalnya mengubah nama sekolah, nama penyusun yang kemudian digunakan untuk memenuhi syarat laporan yang harus diserahkan kepada pihak sekolah diawal semester. Hal ini terjadi karena masih banyak guru-guru yang kesulitan dalam membuat dan merancang RPP.

RPP dapat terealisasi dengan baik dan sesuai dengan harapan jika perangkat pembelajaran yang digunakan dilengkapi dengan LAS. Menurut Andi Prastowo (2017) LAS merupakan suatu bahan ajar cetak yang berupa lembaran-lembaran yang berisi materi, ringkasan dan petunjuk yang harus dilaksanakan oleh siswa. Penggunaan LAS dalam pembelajaran dapat membantu siswa dalam kegiatan pembelajaran dan memudahkan siswa memahami materi yang diberikan sekaligus dapat membantu guru memfasilitasi siswa dalam proses pembelajaran. Hal ini sesuai dengan pendapat Kiki Herdiansyah (2017) yang menyatakan bahwa LAS dapat memudahkan guru dalam membimbing dan memberikan instruksi kepada siswa dan dengan adanya LAS yang sesuai maka siswa dapat terbantu dalam memahami materi yang diajarkan.

Peneliti kemudian melakukan observasi di SMP IT Al-Fitiyah Pekanbaru dan SMPN 25 Pekanbaru diperoleh fakta bahwa proses pembelajaran yang dilakukan belum sepenuhnya sesuai dengan kegiatan pembelajaran yang ada pada Permendikbud Nomor 22 Tahun 2016 dimana guru masih menjelaskan materi pelajaran secara keseluruhan sehingga proses pembelajaran masih berpusat pada guru, kemudian guru memberikan contoh-contoh soal dan memberikan latihan. Hal ini belum sesuai 
dengan Kurikulum 2013 yang mengisyaratkan pembelajaran yang dikehendaki adalah pembelajaran yang melibatkan siswa untuk aktif belajar sehingga proses pembelajaran lebih berpusat pada siswa. Hal ini terjadi dikarenakan kurangnya perencanaan dalam proses pembelajaran, dapat dilihat dari proses pembelajaran di kelas dimana guru hanya menggunakan buku pelajaran dari penerbit yaitu buku matematika kelas VII SMP/MTs Kurikulum 2013 edisi revisi 2016. Penggunaan buku dari penerbit tidak salah namun siswa kurang aktif dan mandiri karena buku yang digunakan hanya berisi materi, contoh soal dan latihan. Sehingga siswa tidak menemukan sendiri konsep matematika yang akan dipelajari. Oleh sebab itu dibutuhkan suatu bentuk perencanaan dalam proses pembelajaran agar pembelajaran sesuai dengan Kurikulum 2013.

Ciri khas pembelajaran pada Kurikulum 2013 adalah kegiatan pembelajaran yang menggunakan pendekatan saintifik. Daryanto (2014) mengungkapkan bahwa pembelajaran dengan pendekatan saintifik adalah proses pembelajaran yang dirancang sedemikian rupa agar siswa secara aktif mengkonstruksi konsep, hukum atau prinsip melalui tahapan-tahapan mengamati, merumuskan masalah, mengajukan hipotesis, mengumpulkan data dengan berbagai teknik, menganalisis data, menarik kesimpulan dan mengkomunikasikan konsep, hukum atau prinsip yang ditemukan. Dalam pendekatan saintifik, siswa perlu dan harus terlibat mengkonstruksi pemahaman melalui penalaran oleh diri sendiri maupun dalam kelompok diskusi atau suatu kelompok kecil yang membahas suatu materi belajar. Guru lebih bersifat sebagai fasilitator dalam proses membangun pengetahuan tersebut. Oleh karena itu, peneliti mengembangkan perangkat pembelajaran yaitu silabus, RPP dan LAS yang mengacu pada Kurikulum 2013 sebagai bentuk perencanaan dalam proses pembelajaran.

Pengembangan perangkat pembelajaran yang dikembangkan disesuaikan dengan model pembelajaran yang digunakan. Rusman (2016) berpendapat bahwa guru dituntut memilih model pembelajaran yang dapat memacu semangat setiap siswa untuk secara aktif terlibat dalam pengalaman belajarnya. Model pembelajaran yang digunakan juga harus dapat membuat siswa merasa tertarik untuk mengikuti kegiatan pembelajaran. Untuk menciptakan pembelajaran yang menarik guru dapat mengaitkan materi pembelajaran ke dalam kehidupan nyata, karena matematika sangat erat kaitannya dengan permasalahan-permasalahan dalam kehidupan sehari-hari. Salah satu alternatif model pembelajaran yang ada pada Kurikulum 2013 sekaligus menuntut siswa untuk berkreativitas dalam pembelajaran siswa adalah model Creative Problem Solving (CPS).

Model pembelajaran Creative Problem Solving merupakan model pembelajaran yang lebih menekankan kreativitas sebagai kemampuan dasar siswa dalam memecahkan suatu permasalahan, serta menuntut siswa berperan aktif dalam pembelajaran dan menuangkan ide-idenya untuk memperoleh solusi penyelesaian permasalahan yang diberikan (Huda, 2013). Melalui model ini, siswa tidak hanya belajar tentang konsep materi belaka melainkan siswa juga dituntut untuk aktif dan kreatif agar dapat menyelesaikan permasalahan. Penggunaan model CPS diharapkan dapat mengubah kondisi belajar yang pasif menjadi aktif dan kreatif. Hal ini sejalan dengan hasil penelitian yang dilakukan oleh Windi dan Aldila (2016) dalam jurnalnya mengungkapkan bahwa dengan menggunakan model pembelajaran 
Creative Problem Solving mampu meningkatkan kemampuan berpikir kreatif siswa. Yuli Sulistyowati (2014) juga mengatakan dalam penelitiannya bahwa dengan menggunakan model CPS yang digunakan dalam pembelajaran dapat membuat pembelajaran menjadi lebih efektif. Dari penelitian-penelitian tersebut, maka peneliti perlu mengembangkan perangkat pembelajaran (RPP dan LAS) dengan menggunakan model pembelajaran CPS dimana isi dan konsep yang disusun relevan bagi siswa sehingga mampu meningkatkan kreativitas dan membuat siswa aktif dalam pembelajaran.

Salah satu materi yang berhubungan dengan model pembelajaran CPS adalah aritmatika sosial yang mempelajari mengenai nilai suatu barang, harga penjualan dan pembelian, persentase untung dan rugi, dan sebagainya. Aritmatika Sosial diajarkan di kelas VII SMP pada semester genap. Aritmatika sosial merupakan salah satu cabang ilmu matematika yang penggunaannya sangat erat dengan permasalahan kontekstual sehingga perlu menunjukkan secara nyata kepada siswa untuk kreatif dalam menyelesaikan masalah materi aritmatika sosial. Hal ini sejalan dengan hasil observasi yang dilakukan peneliti pada dua sekolah yang ada di Pekanbaru, bahwasannya siswa kesulitan dalam menyelesaikan masalah pada materi aritmatika sosial. Masjudin (2016) mengatakan bahwa siswa seringkali hanya menghafal rumus-rumus yang telah diperolehnya sehingga mereka sulit dalam menyelesaikan masalah, terutama masalah- masalah kontekstual. Oleh karena itu perlu adanya pengembangan perangkat dimana isi dan konsep yang disusun relevan bagi siswa dan akan memberi makna dalam proses pembelajaran.

Perangkat pembelajaran yang dihasilkan harus memenuhi kategori valid dan praktis. Dimana valid maksudnya adalah ukuran yang menunjukkan tingkat kesahihan suatu perangkat pembelajaran dan praktis maksudnya adalah suatu tindakan yang dilakukan oleh pengguna produk perangkat pembelajaran untuk mengukur tingkat keterlaksanaan produk yang dikembangkan. Oleh karena itu perlu dilakukan pengembangan perangkat yang valid dan praktis melalui sebuah penelitian. Untuk mewujudkan gagasan ini, maka peneliti akan melaksanakan sebuah penelitian dengan judul "Pengembangan perangkat pembelajaran matematika (Silabus, RPP dan LAS) berbasis Creative Problem Solving pada materi aritmatika sosial SMP/MTs.

\section{METODE}

Penelitian ini menggunakan jenis penelitian Research and Development (R\&D) atau dikenal dengan istilah penelitian pengembangan. Penelitian ini bertujuan untuk menghasilkan perangkat pembelajaran matematika berupa silabus, RPP dan LAS melalui penerapan model pembelajaran berbasis Creative Problem Solving pada materi pokok aritmatika sosial di kelas VII yang akan diuji kevalidan dan kepraktisannya.

Pada penelitian ini, model penelitian pengembangan yang digunakan adalah model 4-D. Model penelitian dan pengembangan 4-D dikembangkan oleh Thiagarajan (dalam Trianto, 2015) model 4-D meliputi kegiatan yaitu: (1) Define (pendefenisian); (2) Design (perancangan); (3) Develop (pengembangan); (4) Desseminate (penyebaran). Model 4-D dipilih karena pada model ini terdapat analisis kebutuhan yang sesuai dengan masalah yang melatar belakangi penelitian yang dilakukan. 
Dengan adanya analisis kebutuhan, melihat karakteristik peserta didik dan dengan kondisi yang ada maka diharapkan dengan model ini dapat dikembangkan perangkat pembelajaran matematika berupa silabus, RPP dan LAS melalui penerapan model Creative Problem Solving (CPS) yang bermanfaat dalam proses pembelajaran di sekolah. Perangkat pembelajaran matematika dikembangkan untuk materi aritmatika sosial di kelas VII yang valid dan praktis.

Setelah data dikumpulkan, maka semua data tersebut akan dianalisis untuk melihat hasilnya. Pada penelitian ini, teknik analisis data yang digunakan adalah analisis dekriptif. Analisis data dilakukan dengan menghitung hasil validasi dari para pakar. Perangkat pembelajaran yang akan divalidasi yaitu silabus, RPP dan LAS.

1. Analisis hasil validasi silabus, RPP dan LAS

Hasil validasi silabus, RPP dan LAS dianalisis menggunakan nilai rata-rata (mean) dengan rumus berikut.

$$
\bar{T}_{v}=\frac{\sum_{i=1}^{n} \bar{V}_{i}}{n}
$$

(Adaptasi Anas Sudijono, 2011)

Keterangan:

$\bar{T}_{v}=$ rata-rata total validasi

$\bar{V}_{i}=$ rata-rata validasi validator $\mathrm{ke}-\mathrm{i}$

$n=$ banyaknya validator

Penentuan rentang dapat diketahui melalui skor tertinggi dikurang skor terendah dibagi dengan skor tertinggi. Berdasarkan penentuan rentang tersebut diperoleh rentang 0,75. Adapun kriteria validasi analisis rata-rata yang digunakan dapat dilihat pada Tabel 1 berikut.

Tabel 1. Kategori Validitas Silabus, RPP dan LAS

\begin{tabular}{|c|c|}
\hline Interval & Kategori \\
\hline $3,25 \leq \bar{T}_{v}<4$ & Sangat valid \\
\hline $2,50 \leq \bar{T}_{v}<3,25$ & Valid \\
\hline $1,75 \leq \bar{T}_{v}<2,50$ & Kurang Valid \\
\hline $1,00 \leq \bar{T}_{v}<1,75$ & Tidak Valid \\
\hline
\end{tabular}

Suharsimi Arikunto, 2012

2. Analisis hasil angket siswa

Analisis data hasil respon siswa untuk menilai kepraktisan LAS yang dikembangkan. Analisis kepraktisan perangkat pembelajaran menggunakan angket respon siswa dapat dilakukan dengan rumus berikut.

$$
\bar{T}_{p}=\frac{\sum_{i=1}^{n} \bar{p}_{i}}{n}
$$

(Adaptasi Anas Sudijono, 2011)

Keterangan: 
$\bar{T}_{p}=$ rata-rata total praktikalitas

$\bar{p}_{i}=$ rata-rata praktikalitas praktisi ke-i

$n=$ banyaknya praktisi

Adapun kriteria kepraktisan dari perangkat pembelajaran berupa LAS dapat dilihat pada Tabel 2 berikut.

Tabel 2. Kriteria Tingkat Kepraktisan

\begin{tabular}{|c|c|}
\hline Interval & Kategori \\
\hline $3,25 \leq \bar{T}_{p}<4$ & Sangat praktis \\
\hline $2,50 \leq \bar{T}_{p}<3,25$ & Praktis \\
\hline $1,75 \leq \bar{T}_{p}<2,50$ & Cukup Praktis \\
\hline $1,00 \leq \bar{T}_{p}<1,75$ & Tidak Praktis \\
\hline
\end{tabular}

Suharsimi Arikunto, 2012

\section{HASIL DAN DISKUSI}

Pengembangan perangkat pembelajaran matematika pada penelitian ini dilakukan dengan pengembangan model 4-D yang meliputi 4 tahapan, yaitu tahap Define (pendefenisian), tahap Design (perancangan), tahap Development (pengembangan) dan Desseminate (penyebaran). Pada tahap Define (pendefenisian) Kegiatan yang dilakukan pada tahap ini untuk menetapkan dan mendefenisikan syaratsyarat pengembangan perangkat pembelajaran matematika (Silabus, RPP, dan LAS). Kebutuhan pada tahap ini meliputi analisis awal-akhir, analisis siswa, analisis konsep, analisis tugas, dan spesifikasi tujuan pengembangan. Hasil pada tahap Define ini adalah dibutuhkan perangkat pembelajaran yang mengacu pada Kurikulum 2013. Berdasarkan analisis siswa, dibutuhkan model Creative ProblemSolving agar dapat melatih siswa untuk menyelesaikan masalah kontekstual, dan pembelajaran dapat lebih bermakna dan berpusat pada siswa. Pengembangan silabus, RPP dan LAS juga dapat mendukung tercapainya tujuan pembelajaran pada kurikulum 2013.

Pada tahap Design (perencanaan), peneliti membuat bentuk dasar (prototype) dan menyusun perangkat pembelajaran matematika berupa silabus, RPP, dan LAS. Adapun kebutuhan pada tahap ini adalah merancang perangkat pembelajan, merancang lembar validasi perangkat pembelajaran untuk validator dan merancang lembar kepraktisan perangkat pembelajaran. Hasil pada tahap Design (perencanaan) adalah peneliti menemukan bentuk dasar (prototype) dari perangkat pembelajaran yang kebutuhan pada pada tahap ini. Adapun bentuk dasar (prototype) dari dari perangkat pembelajaran tersebut dibagi menjadi:

\section{Silabus}

Komponen silabus yang dirancang mengacu pada Permendikbud Nomor 22 tahun 2016 yang mencakup: (1) identitas sekolah; (2) identitas mata pelajaran; (3) kelas/semester; (4) materi pokok; (5) alokasi waktu; (6) kompetensi inti; (7) kompetensi dasar; (8); materi pembelajaran; (9) indikator pencapaian kompetensi; (10) kegiatan pembelajaran; (11) penilaian; (12) alokasi waktu untuk setiap pertemuan; dan (13) sumber belajar 


\section{Rencana Pelaksanaan Pembelajaran (RPP)}

Komponen RPP yang dikembangkan mengacu pada Permendikbud Nomor 22 tahun 2016, yang mencakup : (1) identitas sekolah (nama satuan pendidikan); (2) identitas mata pelajaran; (3) kelas/semester; (4) materi pokok; (5) materi pembelajaran (6) alokasi waktu; (7) tujuan pembelajaran; (8) kompetensi dasar dan indikator pencapaian kompetensi; (9) deskripsi materi pembelajaran; (10) pendekatan/metode/metode pembelajaran; (11) media pembelajaran; (12) alat/media/sumber belajar; (13) langkah-langkah pembelajaran; (14) penilaian hasil pembelajaran.

IPK dan tujuan pembelajaran yang telah dirumuskan, dirancang RPP untuk 5 pertemuan dan setiap RPP digunakan untuk satu pertemuan. RPP-1 berisi materi penjualan, pembelian, untung dan rugi dengan alokasi waktu $3 \times 40$ menit, RPP- 2 berisi materi persentase untung dan rugi dengan alokasi waktu $2 \times 40$ menit, RPP-3 berisi materi diskon alokasi waktu $3 \times 40$ menit, RPP-4 berisi materi bruto, tara dan netto dengan alokasi waktu $2 \times 40$ menit dan RPP-5 berisi materi bunga tunggal dengan alokasi waktu $3 \times 40$ menit.

\section{Rancangan Lembar Aktivitas Siswa (LAS)}

Lembar Aktivitas Siswa (LAS) yang dikembangkan menggunakan model Creative Problem Solving pada materi Aritmatika sosial dengan memperhatikan kelayakan isi, kesesuaian penyajian dengan model pembelajaran, kesesuaian syarat didaktis, syarat konstruksi dan syarat teknis. Sesuai dengan rancangan RPP, LAS juga dirancang menjadi 5 pertemuan. Dengan demikian terdapat 5 LAS yang disusun untuk tiap pertemuan. Setiap LAS memuat tentang konsep dasar dari aritmatika sosial. Kegiatan di dalam LAS mengacu pada model Creative Problem Solving yaitu klarifikasai masalah, pengungkapan gagasan, evaluasi dan seleksi dan implementasi. LAS dirancang sesuai hasil analisis kurikulum dan referensi yang digunakan peneliti. Rancangan LAS yang dibuat oleh peneliti dapat dilihat pada Gambar 3, 4 dan 5 berikut.

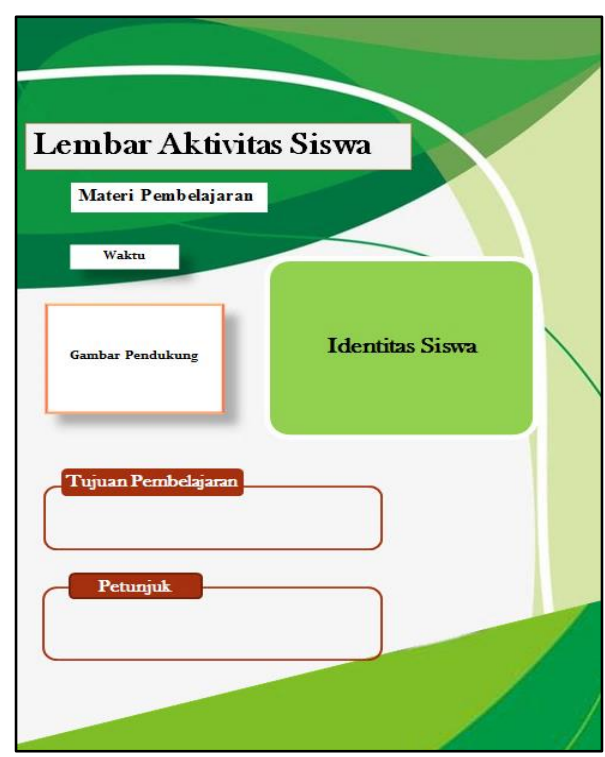

Gambar 1. Rancangan halaman depan LAS 


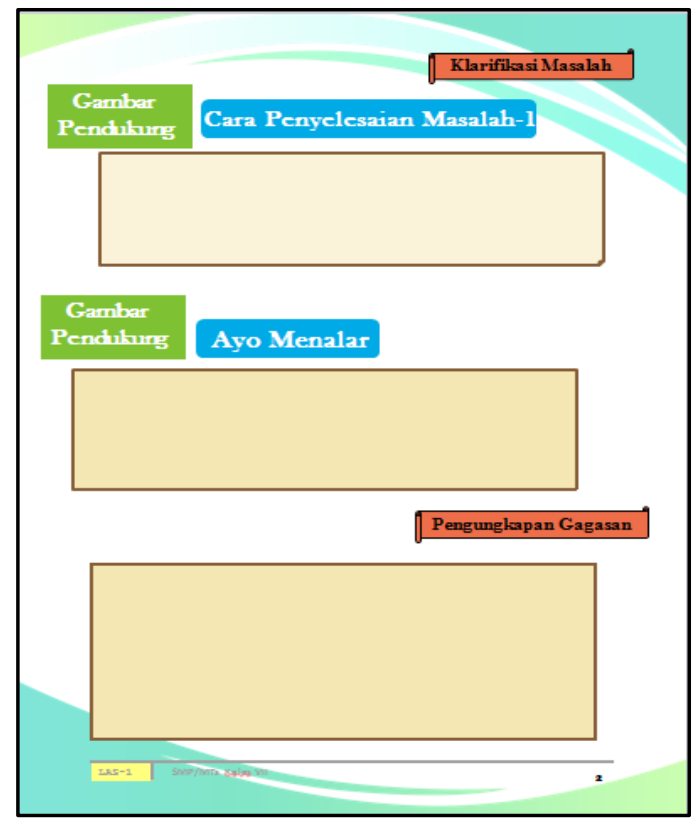

Gambar 2. Rancangan isi LAS klarifikasi masalah dan pengungkapan gagasan

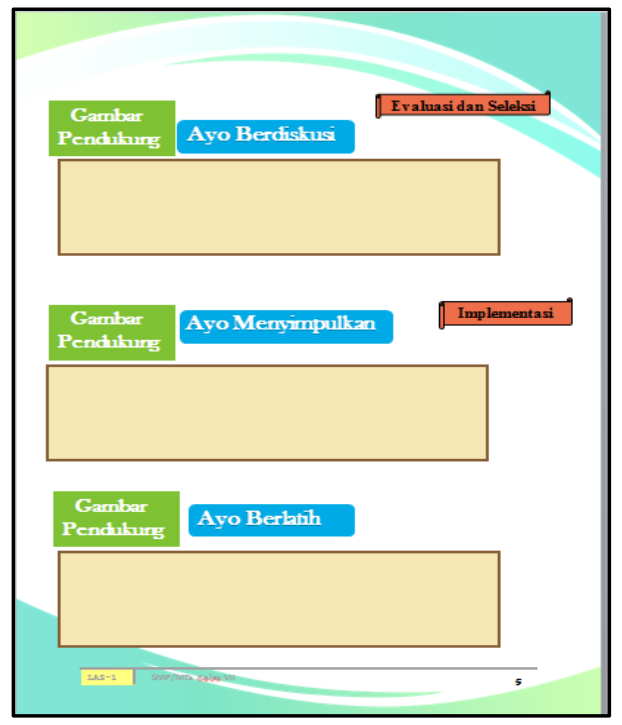

Gambar 3. Rancangan isi LAS evaluasi dan seleksi beserta implementasi

Pada tahap develop (pengembangan) dilakukan dua kegiatan yaitu validasi dan uji coba perangkat pembelajaran. Kegiatan validasi pada tahap develop (pengembangan) adalah memvalidasi Silabus, RPP dan LAS yang telah selesai disusun, dikonsultasikan dan disetujui oleh dosen pembimbing kemudian divalidasi oleh validator. Validasi oleh ahli dilakukan dengan tujuan memperoleh penilaian dan saran perbaikan terhadap silabus, RPP dan LAS yang dikembangkan. Adapun validator yang dipilih dalam penelitian ini adalah 2 orang dosen pendidikan matematika Universitas Riau dan seorang guru SMPN 6 Rambah Rokan Hulu.

Hasil validasi silabus dengan model Creative Problem Solving pada materi Aritmatika Sosial di kelas VII SMP/MTs dibuat dalam bentuk nilai rata-rata dari tiga validator yang dapat dilihat pada Tabel 4 berikut. 
Tabel 4. Nilai Rata-rata dari Tiga Validator untuk Silabus

\begin{tabular}{|c|c|c|c|c|c|}
\hline \multirow{2}{*}{ Nama Perangkat } & \multicolumn{3}{|c|}{$\begin{array}{c}\text { Nilai Rata-Rata dari } \\
\text { Ketiga Validator }\end{array}$} & $\begin{array}{c}\text { Rata-rata } \\
\text { Nilai } \\
\text { Validasi }\end{array}$ & $\begin{array}{c}\text { Kategori } \\
\text { Validasi }\end{array}$ \\
\cline { 2 - 4 } & $\mathbf{1}$ & $\mathbf{2}$ & $\mathbf{3}$ & Sangat Valid \\
\hline Silabus & 3,88 & 3,88 & 3,34 & 3,70 & Sang \\
\hline
\end{tabular}

Rata-rata nilai yang diberikan validator pada silabus untuk aspek kelengkapan identitas silabus, kesesuaian KD dengan IPK dan materi pembelajaran, kesesuaian langkah-langkah pembelajaran dengan model tipe CPS, penilaian hasil belajar, alokasi waktu, sumber belajar dan bahasa. berdasarkan analisis hasil validasi silabus oleh validator, rata-rata nilai validasi untuk silabus adalah 3,70 dan dikategorikan sangat valid. Hasil validasi RPP dan LAS matematika dengan model Creative Problem Solving pada materi Aritmatika Sosial kelas VII SMP/MTs dibuat dalam bentuk nilai rata-rata dari tiga validator yang dapat dilihat pada Tabel 5. berikut ini.

Tabel 5. Nilai Rata-rata dari Tiga Validator untuk RPP dan LAS

\begin{tabular}{|c|c|c|c|c|c|c|c|c|}
\hline \multirow{2}{*}{ No } & \multirow{2}{*}{$\begin{array}{c}\text { Nama } \\
\text { Perangkat }\end{array}$} & \multicolumn{5}{|c|}{ Nilai Rata-Rata dari ketiga } & Rata- & $\begin{array}{c}\text { Kategori } \\
\text { Vata }\end{array}$ \\
\cline { 3 - 9 } & $\mathbf{1}$ & $\mathbf{2}$ & $\mathbf{3}$ & $\mathbf{4}$ & $\mathbf{5}$ & & \\
\hline 1 & RPP & 3,57 & 3,59 & 3,52 & 3,58 & 3,61 & 3,57 & $\begin{array}{c}\text { Sangat } \\
\text { Valid }\end{array}$ \\
\hline 2 & LAS & 3,49 & 3,55 & 3,55 & 3,57 & 3,57 & 3,55 & $\begin{array}{c}\text { Sangat } \\
\text { Valid }\end{array}$ \\
\hline
\end{tabular}

Rata-rata nilai yang diberikan validator pada RPP untuk aspek komponen kelengkapan RPP, kejelasan rumusan indikator pencapaian kompetensi, kejelasan rumusan tujuan pembelajaran, rumusan materi pembelajaran, kesesuaian media, alat, bahan dan sumber belajar, kesesuaian komponen pembelajaran dengan model pembelajaran berbasis Creative Problem Solving (CPS), penilaian hasil belajar dan bahasa. berdasarkan hasil validasi rpp oleh validator, rata-rata hasil validasi untuk rpp adalah 3,57 dan dikategorikan sangat valid.

Rata-rata nilai yang diberikan validator pada LAS untuk aspek komponen las, kesesuaian materi pembelajaran, kualitas kegiatan pembelajaran, kesesuaian las dengan pendekatan saintifik dan berbasis Creative Problem Solving (CPS), kesesuaian dengan syarat didaktis, kesesuaian dengan syarat konstruksi dan kesesuaian dengan syarat teknis. berdasar analisis hasil validasi las oleh validator, ratarata hasil validasi LAS adalah 3,55 dan diaktegorikan sangat valid.

Berdasarkan analisis data hasil validasi oleh validator terhadap silabus, RPP dan LAS dengan menggunakan model Creative Problem Solving pada materi aritmatika sosial untuk kelas VII SMP/MTs, dengan rata-rata skor untuk silabus 3,70, rata-rata skor untuk RPP 3,57, rata-rata skor untuk LAS 3,55. Secara keseluruhan silabus, RPP dan LAS dinilai sangat valid. Validator menyatakan silabus, RPP dan LAS layak diuji cobakan dengan revisi sesuai saran. 
Pada kegiatan kedua pada tahap develop (pengembangan) adalah uji coba perangkat pembelajaran. Subjek penelitian pada uji coba kelompok kecil adalah sebanyak 6 orang siswa kelas VII SMP IT Al-Fitiyah Pekanbaru yang dipilih secara acak dan heterogen dengan jenis kelamin yang berbeda dan tingkat kemampuanyang berbeda pula yang terdiri dari 2 orang berkemampuan tinggi, 2 orang berkemampuan menengah, dan 2 orang berkemampuan rendah. Hal ini dilihat dari nilai ulangan harian yang didapat sebelumnya. Uji coba ini dilakukan untuk melihat praktikalitas LAS dengan menggunakan model Creative Problem Solving, pada materi aritmatika sosial untuk kelas VII SMP/MTs. Adapun Rata-rata Nilai Angket Respon Siswa dapat dilihat pada Tabel 6 berikut.

Tabel 6. Rata-rata Nilai Angket Respon Siswa

\begin{tabular}{|c|c|c|c|c|c|c|c|}
\hline \multirow[t]{2}{*}{ Indikator yang dinilai pada LAS } & \multicolumn{5}{|c|}{$\begin{array}{l}\text { Rata-rata Nilai Angket } \\
\text { Respon Siswa LAS ke- }\end{array}$} & \multirow{2}{*}{$\begin{array}{l}\text { Rata } \\
\text {-rata }\end{array}$} & \multirow{2}{*}{$\begin{array}{l}\text { Kategori } \\
\text { Validasi }\end{array}$} \\
\hline & 1 & 2 & 3 & 4 & 5 & & \\
\hline $\begin{array}{l}\text { LAS yang disajikan terurut sehingga saya mudah } \\
\text { memahaminya }\end{array}$ & 4,00 & 4,00 & 4,00 & 4,00 & 4,00 & 4,00 & $\begin{array}{l}\text { Sangat } \\
\text { Praktis }\end{array}$ \\
\hline $\begin{array}{l}\text { Saya dapat melakukan kegiatan-kegiatan yang ada } \\
\text { pada LAS karena petunjuk kegiatan yang jelas }\end{array}$ & 3,67 & 3,67 & 3,67 & 3,67 & 3,67 & 3,67 & $\begin{array}{l}\text { Sangat } \\
\text { Praktis }\end{array}$ \\
\hline $\begin{array}{l}\text { Kegiatan yang disajikan pada LAS menimbulkan } \\
\text { rasa ingin tahu saya }\end{array}$ & 3,50 & 3,67 & 3,67 & 3,67 & 3,67 & 3,64 & $\begin{array}{l}\text { Sangat } \\
\text { Praktis }\end{array}$ \\
\hline $\begin{array}{l}\text { Penyajian warna pada LAS membuat saya tertarik } \\
\text { untuk mengerjakannya }\end{array}$ & 3,67 & 4,00 & 4,00 & 3,67 & 4,00 & 3,87 & $\begin{array}{l}\text { Sangat } \\
\text { Praktis }\end{array}$ \\
\hline Penyajian LAS dilengkapi ilustrasi yang menarik & 3,50 & 3,50 & 3,50 & 3,50 & 3,50 & 3,50 & $\begin{array}{l}\text { Sangat } \\
\text { Praktis }\end{array}$ \\
\hline $\begin{array}{l}\text { Tulisan pada LAS jelas sehingga mudah untuk saya } \\
\text { baca }\end{array}$ & 3,33 & 3,33 & 3,33 & 3,33 & 3,33 & 3,33 & $\begin{array}{l}\text { Sangat } \\
\text { Praktis }\end{array}$ \\
\hline $\begin{array}{l}\text { Bahasa yang digunakan pada LAS mudah untuk } \\
\text { saya pahami }\end{array}$ & 3,67 & 3,67 & 3,50 & 3,67 & 3,50 & 3,60 & $\begin{array}{l}\text { Sangat } \\
\text { Praktis }\end{array}$ \\
\hline $\begin{array}{l}\text { Saya dapat memahami petunjuk atau arahan dalam } \\
\text { LAS dengan baik }\end{array}$ & 3,33 & 3,33 & 3,33 & 3,33 & 3,33 & 3,33 & $\begin{array}{l}\text { Sangat } \\
\text { Praktis }\end{array}$ \\
\hline $\begin{array}{l}\text { Kegiatan-kegiatan yang ada pada LAS membantu } \\
\text { saya dalam menemukan rumus dan konsep } \\
\text { mengenai aritmatika sosial }\end{array}$ & 3,33 & 3,33 & 3,50 & 3,33 & 3,50 & 3,40 & $\begin{array}{l}\text { Sangat } \\
\text { Praktis }\end{array}$ \\
\hline $\begin{array}{l}\text { Setelah mengerjakan LAS saya dapat } \\
\text { menyelesaikan soal yang berkaitan dengan } \\
\text { aritmatika sosial }\end{array}$ & 3,17 & 3,17 & 3,17 & 3,17 & 3,17 & 3,17 & $\begin{array}{l}\text { Sangat } \\
\text { Praktis }\end{array}$ \\
\hline $\begin{array}{l}\text { Saya merasa bahwa matematika berguna dalam } \\
\text { kehidupan sehari-hari }\end{array}$ & 3,83 & 3,83 & 3,50 & 3,50 & 3,67 & 3,67 & $\begin{array}{l}\text { Sangat } \\
\text { Praktis }\end{array}$ \\
\hline $\begin{array}{l}\text { Saya dapat membangun sendiri konsep matematika } \\
\text { yang saya pelajari }\end{array}$ & 3,33 & 3,33 & 3,17 & 3,17 & 3,17 & 3,23 & $\begin{array}{l}\text { Sangat } \\
\text { Praktis }\end{array}$ \\
\hline $\begin{array}{l}\text { Mengerjakan LAS membantu saya menyatakan } \\
\text { suatu peristiwa kedalam ide matematika }\end{array}$ & 3,33 & 3,33 & 3,17 & 3,17 & 3,17 & 3,23 & $\begin{array}{l}\text { Sangat } \\
\text { Praktis }\end{array}$ \\
\hline $\begin{array}{l}\text { Setelah mengerjakan LAS saya mampu mempu } \\
\text { membuat model matematika dari peristiwa yang } \\
\text { diberikan }\end{array}$ & 3,33 & 3,33 & 3,17 & 3,17 & 3,17 & 3,23 & $\begin{array}{l}\text { Sangat } \\
\text { Praktis }\end{array}$ \\
\hline Rata-rata & 3,50 & 3,54 & 3,48 & 3,45 & 3,49 & $\mathbf{3 , 4 9}$ & $\begin{array}{l}\text { Sangat } \\
\text { Praktis }\end{array}$ \\
\hline
\end{tabular}

Pada uji coba kelompok kecil, respon siswa terhadap LAS model pembelajaran Creative Problem Solving pada materi aritmatika sosial untuk kelas VII SMP/MTs dikategorikan sangat praktis. hal ini terlihat pada rata-rata nilai kepraktisan LAS pada uji coba kelompok kecil adalah 3,49. Dari hasil 
angket respon siswa pada uji coba kelompok kecil LAS model Creative Problem Solving pada materi aritmatika sosial untuk kelas VII SMP/MTs dapat dikategorikan sangat praktis.

Berdasarkan tahap Define, ditemukan masalah dasar yang dihadapi dalam pembelajaran matematika yaitu masih terbatasnya referensi guru untuk mengembangkan perangkat pembelajaran sehingga guru merasa kesulitan dalam mengembangkan perangkat pembelajaran yang menyebabkan masih terbatasnya perangkat pembelajaran yang sesuai dengan tuntutan kurikulum 2013 pada Permendikbud No 22 Tahun 2016. Selanjutnya melakukan analisis karakteristik, yang mana memiliki kemampuan yang berbeda-beda dengan kemampuan tinggi, sedang, dan rendah. Berdasarkan teori belajar belajar Piaget, pada usia 14-15 tahun kemampuan kognitif remaja termasuk ke dalam tahap operasional formal. berpikir lebih ilmiah, mampu memecahkan masalah melalui percobaan sistematis serta mampu berpikir secara luas dan mengkonstruksi pengetahuannya sendiri dan mengembangkan perhatian tentang masalah sosial dan identitas, sehingga sangat cocok untuk menerapkan kurikulum 2013 yang berpusat kepada siswa. Kemudian dilakukan analisis konsep-konsep terkait materi pembelajaran yang dikembangkan, merumuskan Indikator Pencapaian Kompetensi serta merumuskan tujuan pembelajaran berdasarkan Kompetensi Dasar yang telah ditetapkan.

Selanjutnya peneliti melakukan analisis konsep, peneliti mengidentifikasi konsep-konsep yang akan dikembangkan berdasarkan buku matematika kurikulum 2013 edisi revisi 2016 pada KD Aritmatika Sosial. kegiatan pembelajaran dibagi menjadi 5 pertemuan, pertemuan pertama yaitu berisi materi penjualan, pembelian, untung dan rugi dengan alokasi waktu $3 \times 40$ menit, pertemuan kedua berisi materi persentase untung dan rugi dengan alokasi waktu $2 \times 40$ menit, pertemuan ketiga berisi materi diskon dengan alokasi waktu $3 \times 40$ menit, pertemuan keempat berisi materi bruto, tara dan netto dengan alokasi waktu $2 \times 40$ menit dan pertemuan kelima berisi materi bunga tunggal dengan alokasi waktu $3 \times 40$ menit. Setelah peneliti melakukan analisis konsep, langkah selanjutnya adalah analisis tugas. Pada tahap ini peneliti merumuskan Indikator Pencapaian Kompetensi (IPK) dari KD yang sudah ditentukan. Pada tahap terakhir dari tahap Define adalah Spesifikasi tujuan pembelajaran, yaitu dengan menentukan tujuan pembelajaran dari setiap materi pembelajaran.

Pada tahap Design (perencanaan), kegiatan pengembangan yang dilakukan adalah mendesain perangkat pembelajaran. pada tahap Design ini, peneliti melakukan dua kegiatan yaitu pemilihan media dan pemilihan format. Pemilihan media pada penelitian ini yaitu silabus, Rencana Pelaksanaan Pembelajaran (RPP) dan Lembar Aktivitas Siswa (LAS). Rancangan silabus dan RPP disesuaikan dengan tahapan-tahapan pada model Creative Problem Solving. Penyusunan sistematika silabus dan RPP yang dikembangkan berpedoman pada Permendikbud No. 22 Tahun 2016. LAS yang dikembangkan berisi langkah-langkah untuk menemukan konsep aritmatika sosial sehingga dapat meningkatkan keaktifan siswa dalam kegiatan pembelajaran dan memenuhi syarat konstruksi, didaktis dan teknis.

Pada tahap develop (pengembangan), kegiatan yang dilakukan adalah memaparkan hasil pengembangan yang disesuaikan dengan tahap Design dan validasi dengan 3 orang validator yaitu 2 
orang dosen Pendidikan Matematika FKIP Universitas Riau dan seorang guru matematika SMPN 6 Rambah Rokan Hulu disertai revisi berdasarkan saran dari validator. Kemudian dilakukan analisis data dari hasil yang diperoleh dari validasi silabus, RPP dan LAS dengan nilai minimal valid untuk setiap aspek indikator. Setelah tahap validasi dilakukan, selanjutnya dilakukan uji coba produk yaitu uji coba kelompok kecil untuk melihat praktikalitas produk yang dikembangkan.

Setelah tahap revisi, LAS diuji cobakan pada uji coba kelompok kecil. Pada tahap uji coba kelompok kecil, yang diuji cobakan hanya LAS saja. Berdasarkan hasil yang diperoleh dari uji coba kelompok kecil, diperoleh saran dari responden untuk perbaikan.

\section{KESIMPULAN}

Penelitian pengembangan ini menghasilkan produk berupa perangkat pembelajaran matematika yaitu silabus, RPP dan LKPD dengan menerapkan model Creative Problem Solving pada materi aritmatika sosial untuk kelas VII SMP/MTs. Silabus dan RPP yang dihasilkan telah dinilai valid dan LAS yang dihasilkan telah dinilai valid dan praktis.

\section{UCAPAN TERIMA KASIH}

Ucapan terimakasih ditujukan kepada guru matematika dan siswa di sekolah SMP IT Al-Fitiyah Pekanbaru yang telah mengizinkan peneliti untuk melakukan penelitian ini.

\section{REFERENSI}

Andi Prastowo. 2017. Panduan Kreatif Membuat Bahan Ajar Inovatif: Menciptakan Metode Pembelajaran yang Menarik dan Menyenangkan. Diva Press. Yogyakarta.

Daryanto.2014. Pembelajaran Tematik, Terpadu dan Terintegrasi (Kurikulum 2013). Jogjakarta.Gava Media

Hamza B Uno. 2012. Perencanaan Pembelajaran. Bumi Aksara. Jakarta.

Kiki Herdiansyah. 2017. Pengembangan LKPD Berbasis Model Problem Based Learning untuk Meningkatkan Kemampuan Berpikir Kritis Matematika. Diunduh dari http://digilib.unila.ac.id/25454/3/tesis\%20tanpa\%20 bab\%20 pembahasan. Pdf. Diakses pada tahun 2021.

Masjudin. 2016. Pembelajaran Kooperatif Investigatif Untuk Meningkatkan Pemahaman Siswa Materi

Barisan dan Deret. Diakses dari http://ejournal.Ikippgr imadiun .ac.id/index.php/JEMSVolume 4, Nomor 2, September 2016, hal 76-84. Pada tahun 2021

M. Huda. 2013. Model Pengajaran dan Pembelajaran. Pustaka Pelajar. Yogyakarta.

Permendikbud No.22 Tahun 2016. Tentang Standar Proses Pendidikan Dasar dan Menengah. Kemendikbud. Jakarta.

Rusman. 2016. Model-model Pembelajaran (Mengembangkan Profesionalisme Guru). Raja Grafindo Persada. Jakarta.

Sudijono, Anas. 2011. Evaluasi Pedidikan. Raja Grafindo Persada. Jakarta 
Suharsimi Arikunto. 2012. Prosedur Penelitian Suatu Pendekatan Praktik. Rineka Cipta. Jakarta

Sulistyowati, Yuli. 2014. "Pengembangan Perangkat Pembelajaran Bangun Ruang di SMP dengan Pendekatan Creative Problem Solving. Jurnal Pendidikan Matematika 9 (2): 219-232

Trianto. 2015. Model Pembelajaran Terpadu: Konsep, Strategi, dan Implementasi dalam Kurikulum Tingkat Satuan Pendidikan. Bumi Aksara. Jakarta.

Windi Hadianti. T dan Ekasatya Aldila. A. 2016. Kemampuan Berpikir Kreatif Siswa Melalui Creative Problem Solving. EduMa 5(2): 2086-3918. STKIP. Garut. 